\title{
Decoloniality, ubuntu and human rights in South Africa: a bridge to social justice
}

\author{
By Allison GEDULD*
}

\section{A. Introduction}

After the Berlin conference of 1884, various European countries had agreed on the rules that resulted in the colonisation of various African states. ${ }^{1}$ Colonisation consisted until the 1960s for many countries in Africa. ${ }^{2}$ Despite the absence of a physical colonial presence in many African countries, Eurocentric knowledge systems, cultural traditions and habits remained.

The hegemonic knowledge systems that placed European knowledge at the centre of Africa resulted in a political movement known as decoloniality, in the 1960s already, that was centred around the empowerment of African people and the critique of knowledge created by Western Imperialism. ${ }^{3}$ With the 2015 student protests, there has been a resurgence of debates in South Africa on the progress made by post-colonial governments to eradicate coloniality within its institutions and structures. ${ }^{4}$

In 1996, South Africa adopted a Constitution that entrenches various fundamental rights and pursues the realisation of social justice. ${ }^{5}$ The South African debate around the decolonisation of the legal system is influenced by the fact that the current South African legal system originated, and still retains, parts of the Roman-Dutch and English law which are regarded as conservative and unprogressive.

There have been attempts by courts and legislators to integrate African notions, such as ubuntu, into the South African legal system. uBuntu can broadly be described as a communitarian ethic that requires an interdependent relationship of care between an individual and the community. The question arises whether the Western liberal approach adopted by the South African Constitution adequately protects human rights and serves the broader consti-

* The author is a senior lecturer at the North-West University, Law Faculty. She holds a LLB, BA (Hons), LLM and LLD. Her areas of research include Jurisprudence and Ethics.

1 George Devenish, Cutting the apron strings: the South African experience of decolonisation, 2013, The Journal for Transdisciplinary Research in Southern Africa 334.

2 Dietmar Rothermund, The Routledge Companion to Decolonization, 2000, 1.

3 The reference here is to decoloniality within Africa but the movement exists in certain Asian and South American countries as well.

4 Leslie Le Grange, Decolonising the University Curriculum, 2016 South African Journal of Higher Education 1-2.

5 The preamble of the 1996 South African Constitution state that the Constitution was adopted to "heal the divisions of the past and establish a society based on democratic values, social justice and fundamental human rights.". 
tutional goal of social justice or whether notions such as "ubuntu" is needed, as part of the decoloniality of the South African legal system, to add to the realisation of social justice in South Africa. This paper will address this question by analysing the link between decoloniality, ubuntu and the realisation of human rights in South Africa. The concept of decoloniality will firstly be discussed, thereafter the need for the decolonisation of the common law and well as human rights tradition will be discussed. In the final instance Beadica 231 CC $v$ Trustees for the time being of the Oregon Trust ${ }^{6}$ will be discussed as an example of what the court might have done differently to follow more of a decolonial approach in order to reach a more socially just outcome.

\section{B. Decoloniality}

It is useful to distinguish between decolonisation and decoloniality. Decolonisation refers to the physical removal of colonising powers from a certain area. ${ }^{7}$ Although the physical presence of colonisers are absent and colonial laws repealed, it does not mean that the effects of the period of colonisation did not remain. ${ }^{8}$

Thinkers such as Fanon have written about the long-lasting (psychological) effects on a postcolonial society. ${ }^{9}$ This is largely as a result of the fact that colonial society is prescriptive of the culture and habits of society. In Black Skins, White Masks, Fanon states that black people are trapped in their own blackness. ${ }^{10}$ He elaborates to state that black people in the colonised world grow up with a contemptuous view of their blackness. This contemptuous view is depicted in literature, television and culture, for example. The black person might attempt to take on the habits and language of the coloniser but will never be perceived as the authentic version of what he tries to emulate. This results in what Du Bois and Fanon call "double consciousness". ${ }^{11}$ By double-consciousness is meant the feeling that one is constantly measuring oneself by the standards of another, looking at oneself through the eyes of another. ${ }^{12}$ Within the colonial context it would mean that native cultures are constantly measuring themselves by the standards of colonial authorities. One can imagine that the internal as well as external effect that colonisation has had on a society cannot be eradicated overnight. Maldonado-Torres thus refers to coloniality as "the long-standing patterns of power that emerged as a result of colonialism, but that define culture, labour, intersubjec-

62020 (5) SA 247 (CC).

7 Nelson Maldonado-Torres, On Coloniality of Being, 2007, Cultural Studies 243. Sabelo NdlovuGatsheni, Decoloniality as the future of Africa 2015 History Compass 487.

8 Nelson Maldonado-Torres, On Coloniality of Being, 2007, Cultural Studies 243. Sabelo NdlovuGatsheni, Decoloniality as the future of Africa, 2015 History Compass 487.

9 See in this regard Frantz Fanon Black Skins, White Masks; Frantz Fanon Wretched of the Earth.

10 Frantz Fanon Black Skins, White Masks, London 1986, 11.

11 WEB Du Bois Souls of Black Folk, New York 1903, 9.

12 WEB Du Bois Souls of Black Folk, New York 1903, 9. 
tivity relations, and knowledge production well beyond the strict limits of colonial administration". ${ }^{13}$

Decoloniality has been about changing the above-mentioned patterns of power. Many African countries engaged in a process of decolonisation post-independence. The rationale behind many of these movements were that colonisation left a system that was oppressive, discriminatory and not inclusive of all inhabitants. There was thus a need for a new way of life. A "new humanity" as Fanon would call it. ${ }^{14}$ Fanon distinguishes this "new humanity" from nationalism but rather calls it an "African consciousness". ${ }^{15}$

South Africa's history is complicated by the fact that after it received colonial independence that the discriminatory system of Apartheid was still in place. For this reason it can be said that though South Africa received colonial independence in 1961, in reality it was not a decolonised state and thus could not begin a true process of decoloniality. Devenish ${ }^{16}$ says the following about the early "decolonisation" of South Africa:

It was not a process that had been worked out and negotiated by legitimate representatives of both the white and black populations. Its continued application depended on coercion, and, in its unfolding, frequent inroads were made into the norms of constitutionalism and democratic government - always by recourse to African law and practice of indigenous rule, as perceived by whites. It was not a genuine process of decolonisation, but rather a putative or pseudo one, or one which had the goal of coopting a trained indigenous social class into a political framework.

It is only after the constitutional dispensation that talks about decolonisation started to enter the academic discourse again. Since 2015, there has been a specific movement at academic institutions against decolonising the university curricula and removing structures from a colonial past. This ignited a further debate into the decolonisation of structures such as the law. Literature on the concept of the decoloniality of the South African legal sytem has been scant. ${ }^{17}$ The development of the South African law has rather been positioned within

13 Nelson Maldonado-Torres, On Coloniality of Being, 2007 Cultural Studies 243.

14 Frantz Fanon, Wretched of the Earth, New York 1963, 35.

15 Frantz Fanon, Wretched of the Earth, New York 1963, 246.

16 George Devenish, Cutting the apron strings: the South African experience of decolonisation, 2013, The Journal for Transdisciplinary Research in Southern Africa 332.

17 In this regard I am not speaking of decoloniality of the law curriculum at South African universities but rather decoloniality of the legal system itself. See in this regard Emile Zitzke, A decolonial critique of private law and human rights, 2018 South African Journal on Human Rights 492-516. Isaac Shai, The right to development, transformative constitutionalism and radical transformation in South Africa: Post-colonial and de-colonial reflections, 2019, African Human Rights Law Journal, 494-509. Shireen Hassim, Decolonising equality: the radical roots of the gender equality clause in the South African constitution 2018 South African Journal on Human Rights 342-358. Joel Modiri, Conquest and constitutionalism: first thoughts on an alternative jurisprudence 2018 South African Journal on Human Rights 300-325. 
the transformative constitutionalism context. The next section will look at decoloniality of the South African legal system.

\section{The decolonisation of the South African legal system?}

\section{Common law}

At the outset of the new constitutional dispensation South Africa decided to retain many of it's common law rules and statutory provisions from the Apartheid era. Some overtly discriminatory laws were immediately repealed ${ }^{18}$ but it was furthermore decided that the common law and customary law had to be developed with time in line with the values of the Constitution. This was done by granting judicial discretion to the judiciary in terms of section 39 (2) of the Constitution. ${ }^{19}$

As South African law remained a hybrid legal system with remnants from the colonial era in it's common and statutory law, as well as African customary law that was not based on African people's living law. The common law of South Africa also came with a certain judicial conservatism. The common law legal approach has been described as traditional, positivist, and literal.

It is not difficult to see the relevance of a decolonial and transformative approach towards the common law of South Africa. Many provisions from the common law have been changed by the judicial development of the South African law by way of section 39(2). ${ }^{20}$ Some commentators have argued that the change has been too superficial. ${ }^{21}$

The reaction towards the development of the common law of South Africa has been framed with the transformative constitutional narrative. However, one could ask the question whether a transformative approach of the common law adequately lives up to the demands of decoloniality. Zitzke has argued that it does not. He argues that a decolonial approach towards the private law of South Africa would require a more radical approach. ${ }^{22}$

18 For example Population Registration Act 30 of 1950, The Natives Land Act 27 of 1913 and Group Areas Act 41 of 1950.

19 Dennis Davis, Transformation: The Constitutional Promise and Reality, 2010, South African Journal of Human Rights, 85-86.

20 For example the abolition of the rule of male primogeniture in Bhe case, the abolition of marital power.

21 Dennis Davis, Transformation: The Constitutional Promise and Reality 2010 South African Journal of Human Rights 99-101. Dheeksha Bhana, The development of a basic approach for the constitutionalisation of our common law of contract, 2015, Stellenbosch Law Review, 4.

22 Emile Zitzke, A decolonial critique of private law and human rights 2018 South African Journal of Human Rights 504. 


\section{Human rights and constitutionalism}

Not only has the common law and customary indigenous law of South Africa been critiqued but keeping in mind the decolonial goals of $u b u n t u$, the whole human rights system as a product of modernity has also been critiqued. This criticism stems from the practice of situating human rights theory within the European context or no context at all. ${ }^{23}$ Much of what we know of human rights stems from revolutions that took place in Europe and North America. This would include the French Revolution, the Declaration of Independence and the Holocaust. ${ }^{24}$ However, there have been more revolutions throughout the world that has brought about change that has not been recognised as the basis of human rights systems. These revolutions include conflicts in South America, Haiti and South Africa. ${ }^{25}$

In South Africa, a transformative constitutional approach has been adopted. The aim of transformative constitutionalism has been a large scale project situated in law, designed to changes the morals of society. ${ }^{26}$ The term "transformative constitutionalism" was first framed by Klare and subsequently used by scholars and courts in South Africa. Other than the claim that law is a project that should change the South African society Klare also makes a few other claims. Klare asserts that the best interpretation of the South African Constitution is a post-liberal one. By post-liberal it is assumed that he means an interpretation that is not trapped in the classical liberal notion of human rights. Furthermore, he adds that the following aspects make the Constitution post-liberal one: social rights, a substantive concept of equality, affirmative state duties, participatory governance, multiculturalism and historical self-consciousness. ${ }^{27}$ It is clear from Klare's description that the Constitution places positive duties on the South African government to create a more equal society rather than simply protecting liberties as in a classical liberal design. Klare simply mentions that the Constitution is historically self-conscious. However, does this amount to decoloniality? I would argue that it does not.

It does appear that the South African Constitution aspires to a more socially just society. The concept of social justice generally refers to the manner in which a society distributes it's benefits and burdens. It is my opinion that social justice has many categories. To be socially just as legal system must be aware of the different aspects of society that marginalise and oppress people. It is an understanding of social justice does not interrogate colonial injustice it would be incomplete. To my mind, the South African courts have not

23 Jose-Manuel Barreto, Decolonial Strategies and Dialogue in the Human Rights Field: A Manifesto, 2012, Transnational Legal Theory 5.

24 Jose -Manuel Barreto, Decolonial Strategies and Dialogue in the Human Rights Field: A Manifesto, 2012, Transnational Legal Theory 5.

25 Jose-Manuel Baretto, Decolonial Strategies and Dialogue in the Human Rights Field: A Manifesto, 2012 Transnational Legal Theory 5.

26 Karl Klare, Legal Culture and Transformative Constitutionalism 1998 South African Journal of Human Rights 150.

27 Karl Klare, Legal Culture and Transformative Constitutionalism 1998 South African Journal of Human Rights 153-156. 
sufficiently interrogated the history and future of African identity in their search for social justice. Below I will look at how the courts have attempted to use ubuntu an African concept within the South African legal system.

\section{D. uBuntu and decoloniality}

One such way in which courts have attempted to "Africanise" the South African legal system is by the use of the value of ubuntu. uBuntu as a value can be described as humaneness, compassion and interdependence. It was used in one of the first Constitutional Court cases to abolish the death penalty, $S v$ Makwanyane. ${ }^{28}$ In this matter it was used to show that people cannot lose their humanity and that people cannot be used as a means to an end, for example, imprisoning someone and using it to deter other people from committing crimes. $^{29}$ The value has also been used to highlight the plight of vulnerable and marginalised people such as the poor and homeless in PE Municipality v Various Occupiers. In the matter Sachs J said the following:

Thus, PIE expressly requires the court to infuse elements of grace and compassion into the formal structures of the law. It is called upon to balance competing interests in a principled way and promote the constitutional vision of a caring society based on good neighbourliness and shared concern. The Constitution and PIE confirm that we are not islands unto ourselves. The spirit of ubuntu, part of the deep cultural heritage of the majority of the population, suffuses the whole constitutional order. It combines individual rights with a communitarian philosophy. It is a unifying motif of the Bill of Rights, which is nothing if not a structured, institutionalised and operational declaration in our evolving new society of the need for human interdependence, respect and concern. ${ }^{30}$

Thus far $u b u n t u$ has been used as a constitutional value, which can be regarded as an interpretive tool by the courts to give context to judgments and at times to prevent an unfair or unjust outcome outcome. It begs the question whether another value could also have been used to reach the same outcome, such as substantive equality or human dignity.

Some authors have critiqued the courts for their use of ubuntu. Ramose, for example, is doubtful whether constitutionalisation and the "true" use of $u$ Buntu can be reconciled. ${ }^{31} \mathrm{He}$ argues that $u b u n t u$ cannot be separated from African religion. According to him the African religious understanding of $u b u n t u$ can also not be associated with terms such as prescription, etc. He does not see the South African constitutional project as valid as the rights of

281995 (3) SA 391.

29 S v Makwanyane 1995 (3) SA 391 para 316.

30 PE Municipality v Various Occupiers 2005 (1) SA 217 (CC) para 37.

31 MB Ramose, uBuntu: Affirming a Right and Seeking Remedies in South Africa in Praeg and Magadla, Curating the Archive, 2014, 18. 
many Africans have not been vindicated after their land was stolen in terms of the Natives Land Act of 1913.

On the one hand one should acknowledge that there are different strands of African philosophy and that they do not all conceive of African philosophy as related to African religion. On the other hand Ramose raises a valid point that an injustice has been done to many African people, an understanding of social justice has to grapple with these types of historic injustices as we forge a new South African identity.

In the next section the Beadica 231 v Trustees for the time-being of the Oregon Trust will be discussed.

\section{E. Beadica $231 \mathrm{v}$ Trustees for the time-being of the Oregon Trust}

In this matter the applicants formed part of four closed corporations as part of a black economic empowerment initiative who operated a franchise. ${ }^{32}$ The applicants entered into a lease agreement with the respondent (Oregon Trust). According to the lease agreement the lease had to be renewed after five years. The respondent had received no such intention to renew the lease, which had to be completed in January 2016. During March 2016, at different periods, the applicants enquired as to when a new lease agreement could be drawn up. The applicants received no communication until July 2016 when they were informed to vacate the premises. ${ }^{33}$ The applicants had argued that cancelling the lease agreement would be contrary to public policy and the values of the Constitution. The applicants argued further that they did not have the technical know-how to know that the lease had to be renewed. The Constitutional Court had to decide whether the cancellation of the contract had been fair in light of public policy. ${ }^{34}$

The majority judgment set out the development of the South African law relating to the cancellation of contracts as a result of public policy reasons. The test to be applied was eventually decided in Napier $v$ Barkhuizen, ${ }^{35}$ which involves a two-pronged test. The objective part of the tests investigates whether the contractual provision in question is against public policy. The subjective part of the test investigates whether it would be "unfair and unreasonable" to enforce the contract in the present circumstances of the case. The Barkhuizen test was thus the case that had to be applied to the current case.

The court then proceeded to compare "the rule of good faith" with other civil law jurisdictions, namely, Germany, France, England, Scotland, Canada and Australia. ${ }^{36}$ In the majority judgment, the court explicitly stated that the principle of pacta sunt servanda is not something of the past and that contractual certainty was needed for economic develop-

32 Beadica 231 v Oregan Trust para 2.

33 Beadica 231 v Oregan Trust para 8.

34 Beadica 231 v Oregan Trust para 1.

35 Beadica 231 v Oregan Trust para 21-32.

36 Beadica 231 v Oregan Trust para 61-70. 
ment. ${ }^{37}$ The court continued to emphasise the importance of legal certainty. The court also interestingly made a link economic development and the realisation of constitutional rights: ${ }^{38}$

The fulfilment of many of the rights promises made by our Constitution depends on sound and continued economic development of our country. Certainty in contractual relations fosters a fertile environment for the advancement of constitutional rights. The protection of the sanctity of contracts is thus essential to the achievement of the constitutional vision of our society. Indeed, our constitutional project will be imperilled if courts denude the principle of pacta sunt servanda.

The court found that the applicants had failed to prove why they had not renewed the leases on time. ${ }^{39}$ The court also emphasised that the appeal had to be granted as it would give other black economic empowerment initiative beneficiaries the idea that not enforcing the contractual term would result in equality. ${ }^{40}$ Regarding values and $u b u n t u$ the court had stated that values are important but that values do not have a self-standing right. ${ }^{41}$

There is much to be critiqued from a decolonial perspective in the judgment. Many of the points of critique do come out in the two minority judgments.

Firstly, the majority of the court were at pains to emphasise the importance of legal certainty. Legal certainty was also used as a reason to shy away from engaging with values and their application to the matters at hand. Victor AJ, in his minority judgment, touched upon this aspect by stating that there can never be absolute certainty. In quoting Davis J, he calls legal certainty a "shibboleth". ${ }^{42}$ It would be impossible to say that there could only be one right answer in each matter.

Secondly, the majority of the court took an a-contextual approach towards the entire matter. A decolonial approach would question patterns of power and the ways in which law and the rules of contract regulate market relations. Froneman J, critiqued this position in his minority judgment. He mentioned that the South African law of contract is still very much steeped within the classical liberal tradition which favours the protection of property rights. ${ }^{43}$

Froneman $\mathrm{J}$ also critiques the court for their uncritical use of the concepts of "freedom of contract" and pacta sunt servanda. What is of relevance for decoloniality here is that Froneman J comments that the majority of the court seems to assume that prior to the constitutional dispensation in South Africa every person had freedom to contract and that this

37 Beadica 231 v Oregan Trust para 85.

38 Beadica 231 v Oregan Trust para 85.

39 Beadica 231 v Oregan Trust para 102.

40 Beadica 231 v Oregan Trust para 101.

41 Beadica 231 v Oregan Trust para 80.

42 Beadica231 v Oregan Trust para 216. See also Beadica 231 v Oregan Trust (WCC) para 44.

43 Beadica 231 v Oregan Trust para 116. 
notion of freedom of contract is fettered by the use of constitutional values. In reality, the vast majority of South Africans did not have the freedom to contract with whomever they wanted to because it was forbidden by law. ${ }^{44} \mathrm{He}$ continued to state that the law regulated productive and distributive relations. ${ }^{45}$ Froneman $\mathrm{J}$ also acknowledges that there has been a legacy created over centuries of unequal wealth distribution in South Africa and that we cannot say that the "playing field" between all people are level. Froneman J continued to state that he did not see the playing field as level as a result of the history of unequal wealth distribution and the fact that there is an unequal bargaining position between the franchisor and franchisee. ${ }^{46}$

Thirdly, it should be stated that this was a judgment that lent itself towards the interrogation of race in South Africa and the mechanisms that have been provided to advance black businesses. At the very least the majority of the court should have at least investigated the complexities that still exist in South Africa around race and the objectives of the Broad Based Black Economic Empowerment Act. ${ }^{47}$ In the minority judgment of Victor AJ the transformative aspects of $u b u n t u$ were touched upon. He emphasised the fact that ubun$t u$ is a context-sensitive concept. Victor $\mathrm{J}$ stated that seen through the prism of ubuntu, the fact that the franchise and lease agreements were concluded as part of the commercial empowerment of previously disadvantaged persons should have been taken into account.

What is perhaps most regrettable is the ending of the judgment where the court states that the appeal must be dismissed because other people would not want to do business with BEE companies and would think contracts don't have to be enforced. This regrettable firstly as the court laments that abstract values should not be used. In $S v$ Makwanyane, one of the first judges that utilised $u b u n t u$, Mokgoro J emphasised that ubuntu implies that people are not seen as a means to an end. This was one of the main justifications for not using the death penalty as a deterrent. The court in effect did this by not applying the law to the matter at hand but anticipating that business partners will be mistrustful of Black Economic Empowerment Initiatives. The court seems to be misguided in their role which is to judge every case on it's own merit. The court seems to apply that every case dealing with BEE initiave contracts will be the same. This is the very definition of a slippery slope argument.

Lastly, the court seemed hesistant to engage with African jurisprudence. As mentioned above, over a few pages the court refers to a number of European civil law jurisdictions to indicate that "fairness operates differently throughout the world". It is puzzling why the court did this. The foreign jurisprudence didn't add anything of value to their judgment. Why did they only refer to civil law jurisdictions, when they could have engaged substantively with South Africa's own jurisprudence on common law of contract and public policy. Furthermore, Victor $\mathrm{J}$ mentioned that the time had come to vindicate African jurisprudence

44 Beadica 231 v Oregan Trust para 142.

45 Beadica 231 v Oregan Trust para 143.

46 Beadica 231 v Oregan Trust para 200.

4752 of 2003. 
as a system that is different from Eurocentric jurisprudence. ${ }^{48}$ This he stated culminated in the concept of ubuntu.

Decoloniality is about recognising an African identity. It is about recognising the struggle of Africa and South Africa. Decoloniality would require the South African courts to have a deeper engagement with their own history and identity. The court might have said a bit more about the Black Economic Empowerment Act and it's purpose.

\section{F. Conclusion}

This paper has set out to determine whether the Western liberal approach adopted by the South African Constitution can be regarded as a decolonial approach. It was found that while the South African Constitution does have transformative aspirations that could lead to social justice that it does not necessarily lead to a decolonial approach. Such a sense of social justice would be incomplete as it does not take into account the historical injustices that many South Africans and Africans have suffered. In Beadica 231 v Oregon Trust it was illustrated that a decolonial interpretation woud require an interrogation into relations of power as they relate to race and market relations. It was furthermore found that ubuntu might add contextual sensitivity by bringing specific communitarian concerns to the fore. However, a decolonial approach does not have to culminate in the value of ubuntu. Rather, it culminates in the exploration of the past and future of South Africa by the South African judiciary in order to forge new post-colonial identity. 